Jurij Makar

ORCID ID: https://orcid.org/0000-0002-7904-828X

Natalia Rotar

ORCID ID: https://orcid.org/0000-0002-6430-3460

Czerniowiecki Uniwersytet Narodowy imienia Jurija Fedkowycza

\title{
Transformacja kultury wyborczej na Ukrainie: od praktyk autorytarnych do modelu demokratycznego
}

W e współczesnej zachodniej nauce politycznej pojęcie „kultura wyborcza” zwykle jest stosowane do konceptualizacji istoty oraz dynamiki procesów wyborczych w państwach, w których zachodzą procesy systemowych transformacji politycznych, modernizacji politycznej bądź reformowania politycznego z nieokreślonym (nieprognozowanym) wynikiem ${ }^{1}$. Od czasu do czasu za pomocą pojęcia „kultura wyborcza” opisywane są strategie działalności nietypowych dla konkretnego systemu politycznego partii politycznych (na przykład partii z ekocentrycznym, a nie antropocentrycznym widzeniem świata) w procesie elektoralnym państw starej demokracji ${ }^{2}$. Tradycyjnie badania wyborcze amerykańskiej oraz zachodnioeuropejskich szkół naukowych są skoncentrowane dookoła tłumaczenia nie kultury wyborczej, a zachowania wyborczego oraz orientacji wyborczych. Mianowicie w Informatorze oksfordzkim z wyborów amerykańskich oraz zachowania politycznego (2011) w części poświęconej procesom wyborczym ani razu nie wykorzystano pojęcia „kultura wyborcza”. Natomiast całą uwagę skupiono na trzech podstawowych podejściach do analizy zachowania wyborczego: modelach klasycznych szkół columbijskiej i michigańskiej oraz modelu racjonalnego wyboru ${ }^{3}$. Oce-

1 R.W. Jackman, R.A. Miller, The Poverty of Political Culture, "American Journal of Political Science" 1996, vol. 40, № 3, August, p. 712.

2 Electoral Cultures: American Democracy and Choice (Publikationen Der Bayerischen Amerika akademie/Publications of the Bavarian American Academy), ed. by G. Banita, S. Pöhlmann, Universitätsverlag winter Heidelberg, 2015, vol. 16, p. 416.

3 Oxford Handbooks, http://www.oxfordhandbooks.com, L. M. Bartels, "The Study of Electoral Behavior", [in:] Oxford Handbook on American Elections and Political Behavior, ed. Jan Leighly, http://citeseerx.ist.psu.edu/viewdoc/download?doi=10.1.1.408.9896\&rep=rep1\&type=pdf 
niając tradycje badań udziału w wyborach, A. Heath nadmienił, że wszystkie powyżej wymienione mają wspólną cechę, ponieważ centrum ich uwagi badawczej jest wyborca - indywiduum działający w sposób racjonalny, którego wybór elektoralny opiera się na jego przewagach indywidualnych oraz orientacjach partyjnych, wpisanych do systemu czynników endogenicznych oraz egzogenicznych ${ }^{4}$. A. Heath sprowokował całkiem słuszne pytanie na temat tego, na ile model indywidualistyczny badań udziału wyborczego będzie odpowiedni dla rozstrzygnięcia oraz wytłumaczenia wyboru elektoralnego w tych krajach, gdzie proces ten jest określany nie tyle motywami indywidualnymi, co jakimikolwiek zewnętrznymi wobec jednostki czynnikami.

Warto wspomnieć, że jeszcze w podręczniku Głosowanie: badania kształtowania opinii publicznej w kampanii prezydenckiej (1954) sformułowano ostrzeżenia dotyczące nieodpowiedniości porównywania wyboru wyborcy do decyzji konsumenta lub biznesmena: „Dla wielu wyborców preferencje polityczne lepiej jest porównywać z upodobaniami kulturowymi - w muzyce, literaturze" ${ }^{\text {" }}$, ponieważ preferencje artystyczne i wyborcze mają podobne korzenie, których należy się doszukiwać w tradycjach etnicznych, rodzinnych oraz socjalnych. Do tego wszystkiego zarówno upodobania artystyczne, jak i wyborcze ukazują nie tylko względną stabilność, lecz również możliwość zmian: „Podczas gdy obydwa rodzaje przewag zależą od zmieniających się warunków i zachęt, są one stosunkowo niewrażliwe na argumentację bezpośrednią oraz są wrażliwe na pośredni wpływ społeczny. Obydwa rodzaje charakteryzują się w większym stopniu wiarą, niż przekonaniem i są bardziej ukierunkowane na pragnienie oczekiwania, niż na sprognozowane następstwa"'.

I tak, w angielsko-amerykańskim dyskursie politologicznym używane jest pojęcie „kultura wyborcza” odpowiednie dla tych sytuacji, w których zwyczaje społeczne oraz wpływ społeczny są silniejsze niż racjonalny wybór, co jest typowe dla niestabilnych systemów politycznych, w których występują niezakończone procesy systemowych przekształceń politycznych. Naszym zdaniem takie podejście pomija kwestię tego, czym są wybory dla samych obywateli. Na Ukrainie, która należy do kręgu krajów, gdzie trwają procesy transformacji demokratycznej, wybory są nie tylko nieodłączną instytucją polityczną, jest to również narzędzie wykazywania upodobań, możliwość publicznego wyrażenia swojego stanowiska, mechanizm inkorporacji do elit politycznych, pewnego rodzaju rytuał, zwyczaj i obowiązek. Otóż za pomocą pojęcia „kultura wyborcza" są odzwierciedlane postawy obywateli Ukrainy w stosunku do instytucji wyborów w kontekście narodowym oraz transnarodowym.

W naszym badaniu będziemy korzystali z pojęcia „kultura wyborcza” w kontekście procesu politycznego, który przejawia się $\mathrm{w}$ dynamicznych relacjach zachodzących pomiędzy pozycjami wyborcy, kandydata (agitatora) oraz organizatora wyborów. Podsta-

4 A. Heath, Perspectives of Electoral Behavior, "The Oxford Handbook of Political Behavior", ed. R. Dalton, H.-D. Kliengemann, Oxford, N.Y., 2007, p. 611-615.

5 Voting: A Study of Opinion Formation in a Presidential Campaign, ed. B.R. Berelson, F. Lazarsfeld, W.N. McPhee, Chicago, 1954, p. 395.

6 Ibidem, p. 202. 
wową tego rozumienia jest proces odtworzenia działalności wyborczej, czyli systemu działan zapewniających odtwarzanie organów wybieranych władzy politycznej. Badaniu dynamiki transformacji kultury wyborczej będą towarzyszyły konkretyzacje istoty takich wskaźników ich pomiaru, jak (1) kompetencja wyborcza - charakteryzująca cechy wiedzy i specyfiki doświadczenia podejmowania decyzji w warunkach procesu wyborczego, stopień informowania o wyborach oraz poziom zainteresowania nimi, znajomość norm prawa wyborczego i odzwierciedlająca się w intensywności orientacji na partię władzy; (2) dyspozycja wyborcza - dość stabilne i stałe oceny instytucji wyborów przez wyborców, uzasadniona jego doświadczeniem uczestnictwa wyborczego oraz szczególnym systemem postaw, przekonań, spostrzeżeń dotyczących procesu wyborczego, stosunek do instytucji wyborów jako całości i postrzeganie jej realizacji praktycznej, mianowicie stereotypów, ukierunkowań, wartości powiązanych z procesem wyborczym, charakterem motywacji udziału lub nieuczestniczenia w wyborach; (3) aktywność wyborcza - stopień oraz charakter zaangażowania obywatela do procesu wyborczego.

Kształtowanie kultury wyborczej na Ukrainie jest ściśle powiązane z wprowadzeniem ogólnego prawa wyborczego na początku XX wieku, tak więc wraz ze wznowieniem państwowości ukraińskiej w 1991 roku rozpoczął się okres odnowienia oraz rozwoju. Proces zmian kultury wyborczej na Ukrainie jest obecnie niedokończony i odbywa się w trzech podstawowych etapach: (1) etap transformacji obejmujący lata 1989-1996; (2) etap stabilizacji chronologicznie określony latami 1997-2004; (3) etap radykalizacji rozpoczęty w 2004 r. i trwający do czasów współczesnych. Każdy z określonych powyżej etapów jest logicznym odtworzeniem natury systemowych przemian politycznych, dynamicznych procesów w systemie wyborczym oraz wpływu całości czynników strukturalnych rozwoju politycznego.

\section{Etap transformacji (1991-1996)}

Wektor zmian systemu politycznego Ukrainy oraz jej instytucji nie został ustanowiony z zewnątrz, dlatego kierunek transformacji kultury wyborczej jest zorientowany na Zachód, gdzie obywatele mają wpływ na normy oraz zasady modelu demokratycznego, ukształtowanego w głębi społeczeństwa obywatelskiego, co na Ukrainie dotychczas nie zostało wdrożone. Należy zauważyć, że cechą szczególną praktyk politycznych na Ukrainie stało się to, że partie polityczne jako ważny mechanizm kształtowania demokratycznego postrzegania i oceny procesów wyborczych nie wzbudzały zainteresowania obywateli Ukrainy, więc w przestrzeni wyborczej praktycznie nie konkurowały one ze sobą pod kątem programu. W początkowym etapie przemian postsocjalistycznych decydującymi cechami kształtowania tożsamości partyjnych ludności Ukrainy było, po pierwsze, to, że w przeciwieństwie do większości krajów postkomunistycznych Europy Środkowo-Wschodniej na terytorium naszego państwa nie zostały utworzone partie o ideologii retrospektywnej, czyli takie, które zadeklarowały się jako potomkowie partii z okresu walki narodowo-wyzwoleńczej z lat 1917-1921. Po drugie, w warunkach kryzysu politycznego, intensywnego burzenia systemu stosunków społeczno-gospodarczych identyfikacja polityczna odbywała się ze strony obywateli, 
którzy szybciej uświadamiali sobie, z kim się kategorycznie nie zgadzają, co przekreślało pozytywną identyczność partyjną. Na przykład w 1986 roku swoje członkostwo w Partii Komunistycznej Ukraińskiej Socjalistycznej Republiki Radzieckiej zawiesiły 234 osoby, w 1987 r. - 380, 1988 r. - 1862, 1990 r. - 250 951. Ponadto znaczna część członków partii zrywała z nią stosunki bez uzasadnienia na piśmie; w październiku 1990 r. przez niepłacenie składek partyjnych z partii wystąpiło 248,3 tys. komunistów ${ }^{7}$. Zwykle obywatele ci uświadamiali sobie brak kompatybilności w identyfikacji z ideologią danej partii, którą zamierzali popierać. Po trzecie, kryzys polityczny przyczynił się do powstania tożsamości aktualnej (sytuacyjnej), która kształtowała się bezpośrednio w procesie działań politycznych oraz opierała się na osobowości lidera politycznego. Następstwem opisanych powyżej cech stało się nie nakładanie identyczności ideowych na partyjne, co z kolei sprzyja inkorporacji obywateli do struktur partyjnych, a zastępowanie identyczności partyjnych ideologicznymi. Wykazywaniu tej zamiany od jednego cyklu wyborczego do drugiego na poziomie instytucjonalnym, razem z retoryką ukraińskiego establishmentu politycznego, sprzyjało również to, że podstawowa kwestia rozwoju politycznego Ukrainy w latach 1991-1994 była rozwiązywana na płaszczyźnie ideologicznej komunizm-antykomunizm.

$\mathrm{Na}$ etapie początkowym przekształceń postsocjalistycznych zwolenników ideologii lewicowej na Ukrainie było tylko około 8\% (komunistycznej - 3\%, socjalistycznej - 5\%), co można wytłumaczyć zakazem działalności partii komunistycznej oraz nadzieją na szybkie pozytywne zmiany zarówno w sferze politycznej, jak i gospodarczej, które będą przeprowadzane na nowej podstawie ideologicznej. Jednak już w 1994 r. liczba zwolenników ideologii lewicowych wzrosła do $22 \%$ ( $10 \%$ to poparcie ideologii komunistycznej, 11\% - socjalistycznej). Jednocześnie, jeśli w 1992 r. tylko 33\% obywateli Ukrainy nie mogło określić własnych ideologicznych identycznośći, to w 1994 r., w roku przedterminowych wyborów prezydenckich, liczba ta wzrosła do 45,5\%. Jego strukturę określiły dwie płaszczyzny - „póki co nie określili swojej pozycji” (17,9\%) oraz „nie rozumieją się na tych prądach" $(27,6 \%)^{8}$. Równolegle zarejestrowano istotne odchylenie identyczności ideologicznych, kiedy to „większość ludności określa siebie jako zwolennicy ideologii »lewicowych" - komunistycznych lub socjalistycznych i nie identyfikują siebie z odmianami centrystowskiej lub prawicowej"'. Tak więc początek procesu kształtowania identyczności partyjnych obywateli Ukrainy potwierdzil, że partia/identyczność ideologiczna jest zjawiskiem kształtującym się przez dłuższy czas, dlatego nie warto mówić o stałym charakterze przewag polityczno-ideologicznych w pierwszym prezydenckim cyklu wyborczym. Motywy uczestnictwa wyborczego przeważającej większości obywateli Ukrainy

7 В.М. Литвин, Україна: досвід та проблеми державотворення (90-ті роки ХХ ст.), К., Наукова думка, 2001, с. 39-40.

8 Н.В. Паніна, Українське суспільство 1994-2005: соціологічний моніторинг, К., ТОВ „Видавництво Софія”, 2005, с. 26.

9 І.Е. Бекешкіна, Партії і партійне будівництво у соціологічному вимірі, [в:] Українське суспільство: десять років незалежності (Соціологічний моніторинг науковців), ред. В.М. Ворони, М.О. Шульги, К., Ін-т соціології НАНУ, 2001, с. 204. 
były inne - głosowali oni na perspektywę, mając nadzieję, że z biegiem czasu konwertują własne zasoby politycznych w sferze gospodarczej stosunków społecznych.

Charakteryzując początkowy etap transformacji autorytarnego modelu kultury wyborczej na Ukrainie, nadmieńmy, że określał go scenariusz mieszany, który połączył w sobie cechy ewolucji sowieckich wzorów wyboru elektoralnego z przyswajaniem nowych praktyk demokratycznych partycypacji wyborczej. W wymiarze politycznym oznaczało to nieodwracalność procesu transformacyjnego z nieuniknioną perspektywą spadku transformacyjnego. Właśnie dlatego aktywne modele partycypacji politycznej charakterystyczne dla demokratycznej kultury wyborczej, które zapewniły sukces procesów transformacji na początku lat 90 . XX w., już w połowie lat 90 . XX w. przestały dominować w strukturze kultury wyborczej obywateli Ukrainy.

\section{Etap stabilizacji (lata 1997-2004)}

Lata 1997-2004 określamy jako etap stabilizacji kultury wyborczej na Ukrainie, uwzględniając przede wszystkim niezmienność jej cech podstawowych określonych niekompletnością przekształceń demokratycznych i odwróceniem praktyk autorytarnych rządu ukraińskiego. Najbardziej jaskrawym odzwierciedleniem stabilizacji kultury wyborczej Ukrainy w ramach modelu autorytarnego jest rozpowszechniona praktyka autorytarnej mobilizacji wyborców za pomocą narzędzi oraz metod zasobów administracyjnych (dalej: a-zasoby), stosowanych przez aktualne władze do przekonania lub zmuszenia wyborców do głosowania na przedstawicieli władzy. A-zasoby są tym czynnikiem wyboru elektoralnego obywateli Ukrainy, który w przestrzeni politycznej posiada tylko aparat władzy publicznej, dlatego naszym zdaniem należy je zaliczyć do politycznych instytucjonalnych czynników kształtowania kultury wyborczej. Podstawową funkcją a-zasobów jest kształtowanie oraz nawiązywanie wyboru elektoralnego, tak więc w swojej istocie, metodach i celach stosowania przeczą one podstawowym normom demokracji, gdyż zwężają koło podmiotów procesu politycznego do niedozwolonego minimum.

W okresie kampanii wyborczych z lat 1998-2004 ten rodzaj a-zasobów stał się środkiem specyficznej mobilizacji wyborców i w ukraińskim procesie politycznym opierał się na tradycyjnym odtworzeniu relacji patron-klient między elitą a obywatelami. $Z$ reguły inicjatywa wznowienia mobilizacyjnych form uczestnictwa politycznego należała do przedstawicieli władz regionalnych lub lokalnych, którzy wykorzystując je, wykonywali rozkazy rządu centralnego wobec wspierania kursu politycznego i zapewniając własną legitymację. Naszym zdaniem, z jednej strony, relacje patron-klient są reakcją obronną społeczeństwa przed niestabilnością polityczną, z drugiej - tworzyły one istotne przeszkody na drodze do destabilizacji autorytarnego modelu kultury politycznej oraz spowalniały proces uzyskiwania przez nie postaci demokratycznych (1); powstrzymywały kształtowanie systemu poziomych więzi w dziedzinie polityki (2); zastępowały funkcje instytucji społeczeństwa obywatelskiego (3).

Należy podkreślić, że obywatele Ukrainy sprzeciwiali się sztywnym formom a-zasobów. Zgodnie z wynikami sondaży socjologicznych przeprowadzonych w latach 20002001, w przypadku gdy wywierana jest na nich presja przedstawicieli władzy, 57,3\% 
obywateli w każdych warunkach i tak głosuje tak jak uważa za stosowne, 22,7\% - odmawia uczestnictwa w wyborach, $15,1 \%$ - deklaruje, że się podporządkowuje, jednak głosuje tak, jak uważa za dobre dla siebie, i tylko 3,5\% podporządkowuje się i głosuje tak, jak sugerują to przedstawiciele władzy ${ }^{10}$. Pobudziło to władze do stosowania miękkich form a-zasobów wobec wyborców, przede wszystkim tych, którzy należą do dziedziny sytuacyjnego przedwyborczego wsparcia społecznego. Miękkie postacie a-zasobów są pozbawione przymusu bezpośredniego i mogą się objawiać w przekazaniu odpowiedzialności - „głosuj na byle kogo, ufamy ci”; stymulowaniu do opanowania przez wyborcę wzoru ukształtowanego za pomocą technologii komunikacyjnych - „o tym kandydacie opowiadano nam tak wiele dobrego”; zaleceniu głosowania na konkretnego kandydata otrzymanym przez wyborcę od członka komisji wyborczej; ograniczeniu rozpowszechniania informacji o niektórych kandydatach; przymusowym rozpowszechnianiu informacji przez kierowników organów władzy państwowej, przedsiębiorstw, instytucji w celu publicznego poparcia tych lub innych kandydatów; nieprawidłowym układaniu list wyborców - np. „rozdmuchiwanie” list uprawnionych do głosowania w danym okręgu, na miejsce tych, którzy nie mieszkają na jego terytorium, co otwiera większe możliwości dla oszustw powiązanych z kartami wyborczymi; przeprowadzaniu podczas kampanii przedwyborczej akcji społecznych lub udzielaniu pomocy charytatywnej. Ustanowienie bloków imiennych, w których 5-10 pierwszych kandydatów z list wyborczych jest znanymi działaczami publicznymi lub politycznymi, którzy pełnią „, funkcję marchewki, po którą musi posłusznie iść zwykły wyborca”, również można uznać za przykład stosowania przez władze miękkich postaci a-zasobów, zwłaszcza w wyborach parlamentarnych 2002 roku.

Jednym ze wskaźników efektywnego stosowania przez władze a-zasobów jako środka nacisku na obywateli jest szerzenie wśród nich przekonania, że wyniki wyborów będą w taki lub inny sposób zmanipulowane, sfabrykowane, sfałszowane. W roku 1994 takiego zdania było tylko 12\% wyborców, w 1998 r. - 17\%, w 2001 r. - 23,3\%. Na poziomie kultury wyborczej można to odczytać jako wskaźnik niedowierzania wyborom jako mechanizmowi wpływu na władzę, który napędza autorytarne cechy kultury elektoralnej Ukraińców ${ }^{11}$.

Mimo iż stosowanie a-zasobów znajdowało się na skraju legalności oraz było w stanie stworzyć efekt odwrotny - zmniejszenie frekwencji w wyborach, na Ukrainie na etapie stabilizacji kultury wyborczej istniała stała tendencja do korzystania z nich. Czasami a-zasoby celowo uzyskiwały publiczny charakter w okresie przedwyborczym, co doprowadzało do świadomej odmowy wyborców udziału w głosowaniu i tworzyło podstawy do bardziej aktywnego stosowania a-zasobów w fazie głosowania, ponieważ manipulować mniejszą liczbą wyborców (czy kartami do głosowania) jest znacznie łatwiej.

10 I. Жданов, Вибори-2002: соло для адміністративного ресурсу?, “Дзеркало Тижня” 2001, 22 грудня, с. 4.

11 Україна, 2004 рік: перебіг президентської виборчої кампанії очима громадян, "Національна безпека і Оборона" 2004, № 10, с. 6. 
Cechą charakterystyczną etapu stabilizacji kultury wyborczej na Ukrainie stało się kształtowanie tradycji tworzenia partii władzy - „cechujący elity okresu najnowszego sposób reagowania na sytuację $\mathrm{w}$ okresie przejściowym"12, która pretenduje nie tyle do reprezentowania interesów obywateli, ile do kierowania systemem reprezentowania ich interesów, próbując regulować stosunki międzypartyjne oraz decydować o działalności innych partii. Pierwsza próba powołania partii władzy na Ukrainie przypada na okres prezydencji L. Kuczmy, który poparł stworzenie partii „Za jedyną Ukrainę, która w trakcie jego kadencji w latach 1999-2004 reprezentowała interesy obywateli, a także miała udział w zarządzaniu systemem przedstawicielstwa ich interesów, próbując regulować stosunki międzypartyjne, oraz wpływała na działalność innych partii.

Partia władzy bez żadnych manifestacji programowych, struktur organizacyjnych oraz innych cech formalnych prawie natychmiastowo może przekształcić się w jedną z najważniejszych instytucji politycznych reżimu, mimo to charakter identyfikacji z tą partią zawsze będzie miał sprzeczny charakter. Z jednej strony w przejściowych systemach politycznych bardziej potężną ze względu na ilość, niż w demokracjach stabilnych, jest grupa obywateli, która przyzwyczaiła się popierać zwycięzcę i lidera, z drugiej - poszczególne kwestie, które są aktualizowane przez partie władzy, rzeczywiście mogą wywołać reakcję zwrotną u obywateli oraz sprzyjać kształtowaniu identyczności właśnie z tą siłą polityczną. Uwzględniając to, że partia władzy zawsze jest projektem wyborczym zmieniającym swoją optykę wraz ze zmianą bieżącej sytuacji politycznej, właśnie druga kategoria obywateli może zawieść się na polityce oraz udać się do wykorzystania absenteizmu jako podstawowej postaci udziału politycznego.

\section{Etap radykalizacji (2004 r. - obecnie)}

Wraz ze zmianami w systemie wyborczym Ukrainy, które w 1998 r. zaktualizowały funkcje wyborcze partii politycznych, zaczęło się kształtowanie warunków do rozpoczęcia trzeciego etapu w dynamice kultury wyborczej niepodległej Ukrainy, który został utrwalony w pamięci jako aktywne stosowanie form protestu aktywności wyborczej. Przez długi czas w ramach kultury wyborczej Ukrainy istniała możliwość konwencjonalnego głosowania protestowego, opartego na dopuszczalności wykazywania woli zamiarów wyborczych, skierowanych na odmowę poparcia dla wszystkich kandydatów za pomocą skreślania w karcie głosowania wszystkich nazwisk kandydatów lub wybraniu opcji „nie popieram żadnego z kandydatów”. Na Ukrainie podstawowymi czynnikami wyboru wariantu protestacyjnego głosowania było subiektywne uczucie braku satysfakcji z zastanej rzeczywistości, rozbieżność pomiędzy oczekiwaniami a możliwościami zmiany, różnica pomiędzy oceną normatywną a deskrypcyjną reżimu politycznego, niezadowolenie z działalności niektórych instytucji politycznych, brak zaufania do nich. Dla Ukrainy, w której standardy demokratyczne wyborów oraz

12 И.И. Глебова, Беспартийная власть и её партийная организация, [в:] Политическая наука в современной России: время поиска и контуры эволюиии: Ежегодник 2004, М., РОССПЭН, 2004, c. 214. 
procesu wyborczego dość często są naruszane, istnienie wariantu protestacyjnego głosowania było dla jej obywateli szansą na wyrażenie własnego niezadowolenia $\mathrm{z}$ tego, w jaki sposób odbywa się proces wyborów, a politykom dawało rozeznanie w nastrojach społecznych wyborców.

Zwykle składniki protestacyjne kultury wyborczej są aktualizowane wtedy, gdy poszczególne instytucje polityczne nie są w stanie efektywnie pełnić swoich podstawowych funkcji, a partycypacja polityczna obywateli jest w dużej mierze zdeterminowana przez mobilizacyjne praktyki władzy, które wspierają oraz pokazują w systemie stosunków politycznych amorficzny pluralizm oznaczony wysokim stopniem fragmentacji subiektów procesów wyborczych; dzieje się tak w sytuacji, gdy żadna z nich nie jest w stanie zająć dominującej pozycji lub skierować swoich działań na osiągnięcie konsensusu politycznego. Sytuacja ta może sprowokować obywateli do korzystania z aktywnych form protestu wyborczego poza lokalami wyborczymi.

W latach 2004-2018 obywatele Ukrainy dwukrotnie uciekali się do stosowania form protestacyjnych partycypacji politycznej - mowa o pomarańczowej rewolucji oraz rewolucji godności. Stanowisko środowiska naukowego, w tym i nasze, jest pozytywne wobec „aktywnego protestu wyborczego obywateli”, jak miało to miejsce w wyborach prezydenckich w 2004 roku w fazie głosowania.

$\mathrm{W}$ tym kontekście jedną z podstawowych kwestii, która wymaga badań naukowych, jest wyjaśnienie przyczyn niezadowolenia obywateli Ukrainy wobec rozwiązań politycznych, których ujście miało miejsce podczas aktywnego protestu wyborczego w wyborach prezydenckich 2004 r., a nie w wyborach parlamentarnych 2002 roku. Można to tłumaczyć tym, że przywództwo polityczne W. Juszczenki miało znaczne poparcie wśród obywateli, zaś ocena reżimu Ł. Kuczmy była najniższa w całym okresie jego władzy. Pośrednim świadectwem niskiego rankingu „demokracji” kuczmowskiej, swoistą deklaracją tworzenia warunków dla przekształcenia potencjalnego charakteru protestacyjnego uczestnictwa wyborczego na prawdziwy stały się samodzielne oceny obywateli dotyczące możliwości samorealizacji politycznej: w latach 1994-2000 $50,7-60 \%$ z nich deklarowało, że mogli swobodnie wyrażać swoje stanowiska polityczno-ideologiczne, podczas gdy od 2001 r. tego zdania było 35,1\% obywateli; następnie liczby te stale się zmniejszały ${ }^{13}$.

W przeddzień wyborów $84,4 \%$ obywateli uważało, że mają prawo do wyjścia na ulice, aby zaprotestować w przypadku falsyfikacji wyborów, ale we wrześniu 2004 r. tylko 17,0\% uznało, że istnieje możliwość stosowania aktywnych działań dla rewizji wyników wyborów, włącznie z akcjami masowego nieposłuszeństwa obywatelskiego, oraz było gotowych osobiście wziąć w nich udział (w listopadzie ich udział zwiększył się do 19,4\%). Znacząco również wzrósł poziom gotowości protestacyjnej obywateli Ukrainy - $84 \%$ wskazało, że w przypadku naruszenia prawa do swobodnego wyrażania własne-

13 Опозиція в Україні (Аналітична доповідь Центру Разумкова, "Національна Безпека і Оборона" 2002, № 7, c. 28. 
go zdania obywatele Ukrainy mają możliwość wypowiedzieć posłuszeństwo obywatelskie, a 17-19\% potwierdziło gotowość osobistego udziału w ewentualnym proteście ${ }^{14}$.

Naszym zdaniem można wyodrębnić co najmniej trzy przyczyny skutecznej konkurencyjnej mobilizacji politycznej obywateli Ukrainy do wspierania idei pomarańczowej rewolucji. Pierwsza z nich ma charakter instytucjonalny i jest zdeterminowana cechami systemu politycznego Ukrainy. I tak, gdy prezydent państwa posiada większe pełnomocnictwa niż jakakolwiek inna instytucja systemu politycznego, prezydenckie cykle wyborcze przekształcają się dla obywateli na pierwszorzędne, a wybory parlamentarne stają się drugorzędne. Wybory prezydenckie dla ukraińskiego wyborcy są potencjalnie bardziej korzystnym tłem dla protestów - od głosowania protestacyjnego do aktywności protestacyjnej. Rozumiejąc, że instytucja prezydencji ma większy wpływ niż inne w systemie stosunków politycznych, obywatele w drodze uczestnictwa wyborczego starają się mieć wpływ właśnie na niego. W tym kontekście należy rozumieć również przesłankę organizacyjno-polityczną pomarańczowej rewolucji. Faktycznie zwycięstwo W. Juszczenki w wyborach prezydenckich 2004 r. zostało przygotowane w drodze procesu politycznego na Ukrainie w latach 2000-2004. Druga przyczyna pomyślnej mobilizacji politycznej obywateli - technokratyczna - jest związana z brakiem skutecznego mechanizmu reprezentacji całego spektrum interesów społecznych ludności naszego państwa, w wyniku czego został zachwiany bilans interesów między elitą a obywatelami, co z kolei stało się szczególnie zauważalne przed wyborami prezydenckimi w $2004 \mathrm{r}$. Umożliwiło to drużynie W. Juszczenki z powodzeniem wykorzystać jedną z opcji uczestnictwa wyborczego, kiedy to nadmierna nierówność majątkowa, która ma negatywny wpływ na rozwój społeczno-gospodarczy, zawsze doprowadza do destabilizacji reżimu politycznego, natomiast u opozycji pojawia się rzeczywista możliwość poszerzenia granic politycznego uczestnictwa obywateli w procesie politycznym. Na Ukrainie przyczyniło się do tego stosowanie nowego schematu konfrontacji w kampanii prezydenckiej - między etatyzmem W. Janukowycza a podejściem państwowym W. Juszczenki. W drodze aktualizacji problemu wyboru optymalnej strategii między wektorami rozwoju narodowego i demokratycznego drużyna W. Juszczenki spróbowała przekształcić ideę tożsamości narodowej na ideę tożsamości europejskiej, która jest $\mathrm{w}$ stanie zjednoczyć Ukrainę oraz pełnić funkcję legitymacji w procesie przejścia władzy. Ponadto logika wyścigu dwubiegunowego w wyborach 2004 r. doprowadziła do konsolidacji wokół W. Juszczenki różnych przedstawicieli elity politycznej Ukrainy, których cechą wspólną stała się zdolność do zmobilizowania obywateli celem stosowania form protestacyjnych uczestnictwa wyborczego. I tak, po drugiej rundzie wyborów odsetek obywateli, którzy mieli zamiar wystąpić przeciwko fałszowaniu wyników wyborów, wzrósł do $31 \%$, własny udział w akcjach nieposłuszeństwa wykazało prawie $22 \%$ obywateli Ukrainy. W rzeczywistości wraz z protestami przeciwko fałszowaniu wyborów na wiece poparcia dla W. Juszczenki w Kijowie i w innych miastach Ukrainy

14 Україна, 2004 рік: перебіг президентської виборчої кампанії очима громадян, "Національна Безпека і Оборона” 2004, № 10, с. 3. 
zebrało się 50-150 tys. obywateli, a w ciągu tygodnia po drugiej turze wyborów liczba protestujących w Kijowie osiągnęła 1 milion ${ }^{15}$.

Trzeci powód masowego poparcia przez obywateli pomarańczowej rewolucji ma subiektywny charakter: kampania wyborcza w 2004 r. uzyskała cechy wyboru moralno-eschatologicznego między dobrem a złem, prawdą a kłamstwem, sprawiedliwością a niesprawiedliwością, wywołane stosowaniem agresywnych technik politycznych oraz konfliktową retoryką kandydatów. Zgodnie z obliczeniami Komisji Wyborczej Ukrainy sfałszowano około 2,8 miliona głosów, zwłaszcza w obwodach donieckim, ługańskim, zaporoskim oraz mikołajowskim ${ }^{16}$. Ukraińcy, oceniając skalę oszustw i zdając sobie sprawę, że bez odpowiednich wysiłków nie powstaną oraz nie zadomowią się demokratyczne standardy władzy publicznej, nie powstaną rządy prawa, a także nie będą chronione ich prawa polityczne i wolności, wystąpili wspólnie na Majdanie. Wyborcze uczestnictwo polityczne obywateli Ukrainy w tym przypadku miało bardziej autonomiczny charakter.

Pomarańczowa rewolucja wyraźnie określiła kontury nowego (demokratycznego) modelu kultury wyborczej na Ukrainie oraz stała się dla obywateli narzędziem zmieniających się potrzeb i aspiracji w zakresie polityki. Aktywny udział Ukraińców w fazie głosowania przyczynił się do przełamania stereotypu myślenia, że polityka publiczna jest sprawą innych, bardziej przygotowanych ludzi. Wybory prezydenckie w 2004 roku usprawniły kulturę wyborczą, co później zostało potwierdzone w kampaniach wyborczych w latach 2006-2014.

Mimo to stworzone przez pomarańczową rewolucję nowe tradycje demokratyczne kultury wyborczej nie rozwinęły się w kolejnej kadencji w latach 2004-2009. Jedną z przeszkód stało się skierowanie uwagi nowego prezydenta W. Juszczenki w stronę autorytarnych działań, przede wszystkim partii władzy Nasza Ukraina.

Funkcjonowanie partii władzy można scharakteryzować według kilku etapów jej działalności: (1) założenie, (2) wzmocnienie, (3) liderstwo, (4) rozpad. Za początek kształtowania partii władzy W. Juszczenki można uważać jego kampanię wyborczą w 2004 roku, która rozpoczęła się od powołania nowego zrzeszenia obywatelskiego „Za Ukrainu! Za Juszczenka!”, na czele której stanął J. Jechanurow (za czasów przewodnictwa W. Juszczenki w rządzie obejmował stanowisko pierwszego wicepremiera). Sam W. Juszczenko został prezesem honorowym zrzeszenia, a jego brat P. Juszczenko - członkiem rady organizacji. Powołanie zrzeszenia obywatelskiego „Za Ukrainu! Za Juszczenka!" stało się potwierdzeniem deklaracji W. Juszczenki, że będzie kandydował na prezydenta Ukrainy tylko w ramach szerokiej koalicji sił społeczno-politycznych, podczas gdy założenie partii na wzór europejski uważa za krok niezbędny, ale przed-

15 Україна, 2004 рік: перебіг президентської виборчої кампанії очима громадян, "Національна Безпека і Оборона" 2004, № 10, с. 3.

16 Т. Байхельт, Р. Павленко, Президентські вибори і конституційна реборма, [в:] Президентські вибори та Помаранчева революиія: вплив на трансформаційні процеси в Україні, ред. Г. Курта, К. Заповіт, 2005, с. 65. 
wczesny ${ }^{17}$. Taką strategię W. Juszczenki należy uznać za racjonalną, ponieważ po pierwsze, organizacjom społecznym na Ukrainie ufa ponad jedna trzecia ludności, podczas gdy poziom zaufania do partii znajduje się w strefie wskaźników zerowych; po drugie, wysunięcie W. Juszczenki przez organizację społeczną aktualizuje stereotypy masowej świadomości politycznej powiązane z inicjatywami „dołów”. Podczas kampanii wyborczej W. Juszczenko pozycjonował siebie jako zdecydowaną opozycję do istniejącej partii władzy, którą utożsamiano z reżimem $Ł$. Kuczmy. Mimo to jego deklaracje na forach demokratycznych sił, które przeprowadzano pod patronatem Naszej Ukrainy od 13 września 2003 r. - „na sali spotyka się i lewica, i prawica, osoby o różnej ideologii, które nie miały tradycji współpracy politycznej"18 - umożliwiały już wtedy rozmowy o próbach zjednoczenia wyborców eklektycznych, którzy następnie będą wiarygodną podstawą legitymacji partii władzy. Po zwycięstwie w wyborach prezydenckich $2004 \mathrm{r}$., w marcu 2005 r. W. Juszczenko zainicjował instytucjonalne odnowienie Naszej Ukrainy w ramach projektu Sojusz Narodowy (Narodnyj Sojuz) Nasza Ukraina (SNNU). Zaplecze finansowe wdrożenia organizacyjnego partii władzy położono na grupę parlamentarzystów „Razem” (Razom), członkowie stali się podstawowymi dawcami kampanii parlamentarnej Naszej Ukrainy w 2002 r. oraz kampanii prezydenckiej W. Juszczenki w 2004 roku $^{19}$. Jedną z cech formalnych tego, że SNNU w założeniach jest partią władzy, było również to, iż faktycznie zrezygnowała ona z wyraźnych orientacji ideologicznych, typowych dla Naszej Ukrainy 2002 r., zaś celem strategicznym w realizacji misji nowego prezydenta stało się podniesienie poziomu i bezpieczeństwa obywateli oraz uczynienie Ukrainy silną i bogatą.

Wzmocnienie SNNU jako partii władzy odbywało się w kilku kierunkach. Przede wszystkim partia skupiła znaczną uwagę na tworzeniu obwodowych oddziałów partii tylko w ciągu 16-17 kwietnia 2005 r. odbyło się 10 założycielskich konferencji regionalnych organizacji partii oraz założycielska konferencja miejska w Charkowie. Ponadto na czele lokalnych organizacji partyjnych w przewadze stanęli przedstawiciele władz oraz liderzy Naszej Ukrainy w wyborach prezydenckich 2004 r. Na przykład w Czernihowie przewodniczącym oddziału partii został kierownik Obwodowej Administracji Państwowej, były szef sztabu regionalnego W. Juszczenki W. Atroszenko, w Odessie - deputowany Ukrainy, były szef sztabu regionalnego W. Juszczenki O. Kozaczenko, na Wołyniu - zastępca przewodniczącego Wołyńskiej Obwodowej Administracji Państwowej, deputowany Wołyńskiej Rady Obwodowej W. Karpuk, w Iwano-Frankiwsku - prezydent miasta, były szef sztabu regionalnego W. Juszczenki Z. Szkutiak, w Mikołajowie - kierownik Obwodowej Administracji Państwowej O. Sadykow, w Czerniowcach - kierownik Obwodowej Administracji Państwowej M. Tkacz. Pewnie jedy-

17 Я. Галата, Хто сильніше “засмаг”, “Демократична Україна” 2003, 29 серпня, с. 2.

18 Т. Грінчак, Деякі аспекти проведення форумів демократичних сил під егідою блоку В.Ющенка "Наша Україна", “Україна: Події. Факти. Коментарі” 2003, № 20, с. 25-31.

19 Ю. Якименко, А. Литвиненко, И. Жданов, Кто и за что, с кем и против кого? Партии Украинь за год до виборов, “Зеркало Недели” 2005, 2 апреля. 
nym wyjątkiem było wybranie na przewodniczącego Dniepropietrowskiego Oddziału SNNU przedstawiciela biznesu, pierwszego wiceprezesa Narodowej Korporacji Akumulatorowej „ISTA” O. Biłoho, którego interesy lobbował P. Poroszenko.

$\mathrm{Na}$ etapie kształtowania struktury organizacyjnej SNNU w pionie administracyjnym partia zaczęła aktywnie wykorzystywać tradycyjne zasoby dla partii władzy. I tak, podczas tworzenia Donieckiej Organizacji Regionalnej na zjazd nie zaproszono aktywistów organizacji rejonowych oraz byłych przywódców Naszej Ukrainy, którzy chcieli pracować w nowym zrzeszeniu partyjnym; w Ługańsku i Równem konferencje założycielskie zostały zerwane po konfrontacji różnych segmentów regionalnej elity politycznej; na podstawie informacji przekazanej przez lidera UNP J. Kostenkę w obwodach czerniowieckim i lwowskim wywierano presję na członków UNP w celu przymusowego przystąpienia do $\mathrm{SNNU}^{20}$. Oceniając wzmocnienie organizacyjne SNNU kosztem uzyskania członkowstwa w partii przez aktywistów innych sił politycznych, Ł. Łukianenko nadmienil, że „SNNU nie ma perspektywy, ponieważ ta partia tworzona jest pod jednego człowieka" ${ }^{21}$, przez co podkreślił, że SNNU jest faktycznie partią władzy - konkretnym politycznym dziełem, na które może powoływać się prezydent w swoich stosunkach z parlamentem, ponieważ żadnych innych celów programowych, aniżeli wspieranie inicjatyw prezydenckich, ta siła polityczna nie ma.

Zatem dowodem tego, że format SNNU należy określać terminem „partia władzy", jest to, że partia ta bez jakichkolwiek specjalnych manifestacji programowych, podstawowych struktur organizacyjnych oraz innych cech formalnych niemal natychmiastowo przekształciła się w jedną z najważniejszych instytucji politycznych reżimu. Mimo to charakter identyfikacji z partią władzy zawsze ma kontrowersyjny charakter. Z jednej strony, w przejściowych systemach politycznych liczbowo bardziej potężna jest grupa obywateli, którzy przyzwyczaili się do popierania zwycięzcy i lidera, z drugiej zaś strony - poszczególne kwestie, które są aktualizowane przez partię władzy, w rzeczywistości mogą wywołać odwrotną reakcję u obywateli oraz sprzyjać kształtowaniu identyczności właśnie z tą siłą polityczną. Uwzględniając fakt tego, że partia władzy zawsze jest projektem wyborczym, zmieniającym swój charakter wraz ze zmianą aktualnej sytuacji politycznej, a obywatele, którzy identyfikują się z nią, później (pod koniec etapu liderstwa) się na niej zawodzą oraz uciekają się do stosowania absencji jako jedynej manifestacji swojego braku poparcia.

Wystarczająco łatwy odbiór oraz wspieranie nowych partii politycznych na Ukrainie, również wszelkich modyfikacji partii władzy okresu prezydencji W. Juszczenki uzasadnia się tym, że wyboru politycznego obywatele dokonują, głównie wychodząc z założeń konsumenckich, wśród których podstawowa jest orientacja na znane marki. Partia władzy jest zmuszana do aktywnego wykorzystywania mechanizmów brandingu oraz jego personalizacji, dzięki którym jest wypracowywany zbiór wartości oraz idei,

\footnotetext{
20 І. Мищак, Організаційна розбудова партії НСНУ та заходи щзоо підготовки до парламентських виборів, "Україна: Факти. Події. Коментарі” 2005, № 10, с. 44-46.

${ }^{21}$ Ibidem, c. 46.
} 
które spełniają preferencje większości wyborców. Jedyną możliwą drogą reprezentowania interesów masy wyborców jest neutralna (pośrednicząca) pozycja dotycząca różnych interesów wyborców, co znajduje odzwierciedlenie w programie działań i programach wyborczych SNNU22.

Etap liderstwa partii władzy przede wszystkim jest powiązany z procesem wyborczym. Mimo to w sytuacji wyborczej partia władzy nie może być rozpatrywana jako samodzielny podmiot stosunków politycznych - zależy ona od inicjatorów jej powołania, dlatego nie prowadzi walki o władzę, a przedstawia własny udział w wyścigach wyborczych. Cechy takich partii są określane przez popyt rynku politycznego, który jest ustalany za pomocą badań marketingowych oraz socjologicznych. Jednocześnie partia władzy jest zmuszona do formowania poparcia wyborczego na zasadach konkurencyjnych. Działając jako podmiot procesu wyborczego, partia władzy staje się narzędziem uzyskania przewagi wyborczej dla władzy poza systemem artykulacji interesów obywateli. Linia prowadzenia parlamentarnych kampanii wyborczych Naszej Ukrainy była przede wszystkim określana przez status polityczny partii, ponieważ jest to partia proprezydencka (partia władzy), a więc działania w wyborach zależały nie tylko od działań sojuszników-konkurentów z obozu opozycyjnego oraz przeciwników politycznych, ale także od pozycji W. Juszczenki. Dlatego retoryka Naszej Ukrainy zawierała hasła narodowo-patriotyczne, odwołujące się do doświadczeń pomarańczowej rewolucji w połączeniu z krytyką koalicji i rządu. W ten sposób partia władzy pretenduje do roli jedynego źródła i regulatora procesów politycznych, co przede wszystkim odzwierciedla się w cechach strategii informacyjnych partii, które wykorzystuje się podczas wyborów parlamentarnych. Wiele zależało również od tego, w jakim stopniu będzie przekonująca dla publiczności - W. Kyryłenko jako nowa twarz Naszej Ukrainy. Taka linia koalicyjna Naszej Ukrainy doprowadziła do informacyjnego poparcia debaty publicznej na tematy dotyczące zniesienia immunitetu parlamentarnego, całkowitego wsparcia inicjatyw społecznych prezydenta, konieczności wzmocnienia władzy prezydenckiej celem zapewnienia realizacji jego programu wyborczego „Dziesięć kroków w kierunku ludzi" oraz przeciwdziałania kryzysom politycznym, przeprowadzenia reformy sądowniczej i podatkowej.

Partia władzy w wyborach parlamentarnych 2006 roku (Nasza Ukraina) oraz w 2007 roku (SNNU) raczej była zorientowana na wykorzystanie takich technologii informacyjnych pracy z wyborcami, jak po pierwsze, technologia inwestowania w partię czy blok, w sytuacji gdy wpływ na wyborców opiera się na tworzeniu u niego obrazu partii jako jedynej siły politycznej, która jest zdolna do konsolidacji społeczeństwa, przyczynia się do istotnego rozwoju państwa, przezwyciężenia zjawisk kryzysowych

22 Інформаційний портал депутатів, http://old.lvivrada.gov.ua, Програма партії Народний Союз «Нама Україна», доступ: 25.10.2018; Україна у нас одна!: Передвиборна програма Блоку «Наша Україна», “Голос України” 2006, № 35, 23 лютого, с. 4; Центральна виборча комісія України, http://www.cvk.gov.ua, Передвиборча програма Блоку «Наша Україна - Народна самооборона» «Для людей - а не для політиків!», доступ: 25.10.2018. 
oraz stworzenia efektywnej gospodarki lub efektywnego zarządzania państwem; po drugie, technologia inwestowania w lidera partii, kiedy w centrum działalności drużyny kandydata stawiana jest osobowość lidera (W. Juszczenki), który ma przyciągać głosy wyborców. W tym celu są organizowane i wdrażane działania mające na celu wprowadzenie poszczególnej osoby - lidera partii czy bloku - do przestrzeni politycznej, formowanie w świadomości elektoratu niezbędnego wizerunku. W tym kontekście W. Juszczenko był pozycjonowany jako intelektualista, wykwalifikowany specjalista, wyrachowany i rozważny polityk mogący zrealizować idee i aspiracje ludzi, prowadzić za sobą tłumy, zapewnić praworządność. W 2007 roku NSNU zaczęła aktywnie stosować jeszcze jedną technikę - połączenie inwestycji w lidera i partię. W trakcie jej trwania promowano poszczególnych liderów partii jako aktywnych, zorganizowanych i wyszkolonych, silnych politycznie, którzy są w stanie wziąć na siebie odpowiedzialność za przyszłość państwa. Dowodem tego, że Nasza Ukraina w wyborach parlamentarnych otwarcie działała jako partia władzy, jest również to, że koncepcja informacyjna kampanii wyborczej SNNU przypominała wybory parlamentarne w 2006 roku oraz kampanię prezydencką W. Juszczenki, kiedy główne wysiłki skoncentrowano na próbach powiązania wizerunku bloku z osobą W. Juszczenki. Jednakże, biorąc pod uwagę wyniki wyborów z lat 2006 i 2007, przywództwo partii władzy należy uznać jako dość względne, ponieważ w wyborach do Werchownej Rady w 2006 r. blok zajął tylko trzecie miejsce (13,95\% głosów i odpowiednio 81 miejsc w parlamencie), ustępując Partii Regionów i Blokowi July Tymoszenko. W wyborach w 2007 r. SNNU zdobył również trzecie miejsce, uzyskując 14,15\% głosów wyborców i 72 miejsca w parlamencie, co potwierdza początek krystalizacji cech kryzysu partii władzy.

Następstwem trwałego funkcjonowania partii władzy jest powstawanie znacznej luki między realną polityką a formami jej prezentacji dla obywateli Ukrainy. Stanowisko polityczne partii władzy dość często przedstawiane jest obywatelom za pomocą populistycznej retoryki, która stopniowo staje się podstawowym źródłem kryzysu partii rządzącej. Jedną z prób zachowania wymiaru instytucjonalnego SNNU jako partii władzy jest wybranie W. Juszczenki na stanowisko jej szefa. Zdaniem W. Mosyka nie przeczy to ani statutowi partii, ani aktualnemu ustawodawstwu państwa, a jest logicznym krokiem, ponieważ W. Juszczenko jest założycielem Naszej Ukrainy, jej szefem od samego początku i ma legitymację partyjną $\mathrm{Nr} 1^{23}$. Aby uniknąć kolizji z prawem, pierwszy etap szóstego zjazdu SNNU wprowadził odpowiednie zmiany do swego statutu, wprowadzając nowe stanowisko - Przewodniczący Rady Partii, któremu przekazywane są praktycznie wszystkie pełnomocnictwa, wcześniej należące do szefa partii. Jednocześnie szef partii, będąc liderem politycznej SNNU, pozbawiony funkcji wykonawczych, nie jest częścią organów statutowych, a tylko konsoliduje ich pracę.

Zgodnie z deklaracjami prezydenta Ukrainy W. Juszczenki, partia Nasza Ukraina ma przyszłość, ponieważ obecnie w partii trwa usuwanie z list przypadkowych człon-

23 Ліга. Новости, http://news.liga.net, $B$ «Нашей Украине» оправдывают избрание Ющенко главой партии, доступ: 25.10.2018. 
ków, którzy w 2002 r., a następnie w 2004 r. wykupili członkostwo w tej partii. Jednocześnie prezydent zauważył, że SNNU jest w rzeczywistości jedyną partią, która ma wyraźną ideologię i nigdy nie wyrzekła się swoich fundamentalnych pozycji oraz jest w stanie odpowiedzieć na wyzwania stojące przed Ukrainą: „Pozwólcie, że w tej chwili nie będziemy patrzeć na ranking. Pomyślcie każdy o swojej rodzinie, o swoich dzieciach, o swoich wartościach i jakich zmian potrzebujecie. Chcę wam powiedzieć: jeśli dokonacie wystarczającej samoanalizy - nikomu poza Naszą Ukrainą, z przyjemnością nie oddacie wasze głosy"24. Krokiem w kierunku opóźnienie burzenia SNNU jako partii władzy jest ponowna rejestracja członków SNNU, co można odebrać jako wyraźne przywrócenie, wznowienie jej autorytetu i efektywną pracę.

Działalność SNNU udowadnia, że w warunkach demokratyzacji systemu politycznego Ukrainy partia władzy stała się częścią kultury wyborczej, a czasami również pożądanym modelem funkcjonowania elity politycznej, która jest symbiozą starego i nowego segmentu. Stara elita polityczna Ukrainy, kierując się tradycjami samozachowania oraz ciągłego odtwarzania władzy podczas wyborów, wszczepionych w czasach radzieckich, była w stanie narzucić nowej elicie swoje zasady działalności politycznej.

Cechą szczególną procesu wyborczego w wyborach prezydenckich na Ukrainie w 2014 roku było to, że kontekst wyborów był rozpatrywany jako kluczowy (podobnie do wyborów w 1991 r.). Podstawową motywacją uczestnictwa w wyborach wyborcy uważali swój obowiązek obywatelski (57\%), następnie postrzeganie wyborów jako możliwości wpływu na sytuację na Ukrainie (26,5\%) oraz obawy, że w przypadku nieuczestniczenia w głosowaniu głos ten może zostać wykorzystany do fałszerstwa (23,5\%). Szczególnie ważne naszym zdaniem jest to, że główną motywacją do głosowania na liderów kampanii wyborczej były: (1) „widzi rzeczywiste drogi rozwiązania kryzysu gospodarczego oraz zapewni wzrost gospodarczy kraju" (52\% zwolenników P. Poroszenki, 56\% - J. Tymoszenko); (2) „pomysły oraz oferta jest bliska jego wyborcom” (49\% zwolenników P. Poroszenki, 56\% - J. Tymoszenko), (3) „zmoże zjednoczyć obywateli wszystkich regionów oraz przezwyciężyć podział Ukrainy" (34\% zwolenników P. Poroszenki, 50\% - J. Tymoszenko) ${ }^{25}$.

Specyfiką uczestnictwa wyborczego obywateli Ukrainy w 2014 r. stało się również to, że miało ono miejsce w warunkach nieogłoszonej, lecz rzeczywistej wojny z Rosją, co z kolei w pewnym stopniu konsolidowało społeczeństwo ukraińskie i uniemożliwiło wykorzystanie zasobów administracyjnych oraz fałszerwstwo. Ukształtowało to również oczekiwania obywateli w kwestii kursu politycznego P. Poroszenki: stabilizacja sytuacji na Wschodzie, pomyślne przeprowadzenie ATO (Operacji Antyterrorystycznej); natychmiastowe $\mathrm{w}$ wdrożenie reform; wspieranie przeprowadzenia przedterminowych

24 УНIAH, https://www.unian.uа, Ющенко переконаний, щзо у партї Наша Украӥна є майбутнє, доступ: 25.02.2017.

25 Фонд «Демократичні ініціативи імені Ілька Кучеріва», http://dif.org.ua, Вибори-2014: сподівання громадян, рейтинги кандидатів, мотивація вибору, доступ: 24.02.2017. 
wyborów do Rady Najwyższej Ukrainy oraz podpisanie części ekonomicznej Układu Stowarzyszeniowego z UE.

Najbardziej wyrazistym wskaźnikiem kultury wyborczej jest poziom aktywności obywatela jako podmiotu procesu wyborczego w chwili głosowania. Przyjrzyjmy się temu na przykładzie wyborów prezydenta Ukrainy. Najwyższe wskaźniki aktywności wyborczej zarejestrowano w wyborach prezydenckich w 1991 roku. Wtedy w wyborach pierwszego prezydenta Ukrainy wzięło udział 84,32\% wyborców Ukrainy, co z kolei można wytłumaczyć, po pierwsze, czynnikiem automatycznego odtworzenia tradycji radzieckich w partycypacji wyborczej, który był rozumiany przez ludność i propagowany przez władze jako obowiązek, a nie prawo; po drugie, wagą wyborów, które odbywały się jednocześnie z referendum o niepodległość Ukrainy. Maksymalnie zbliżony poziom aktywności obywateli podczas głosowania $\mathrm{w}$ wyborach prezydenta Ukrainy był zarejestrowany w wyborach 2004 r., w procesie powtórnego głosowania 21 listopada ${ }^{26}$. Nadmieńmy, że w wyborach prezydenckich w 2014 roku, mimo iż wybory te były faktycznie wyborem świadomej części Ukrainy, aktywność wyborców wynosiła tylko $59,87 \%{ }^{27}$. W pewnym stopniu można to wytłumaczyć niemożnością wzięcia udziału w głosowaniu przez wyborców anektowanego Krymu oraz tych terytoriów Ukrainy, gdzie doszło do rosyjskiej agresji, przede wszystkim w obwodach ługańskim oraz donieckim. Według wyników badania opinii publicznej przeprowadzonego przez fundację Inicjatyw Demokratycznych, tylko 12,7\% potencjalnych wyborców obwodów ługańskiego oraz donieckiego poinformowało, że ich zdaniem na ich dzielnicach wyborczych trwają wybory. Ponad połowa $(55,1 \%)$ powiedziała, że wybory nie są przeprowadzane i jedna trzecia $(32,2 \%)$ nie wiedziała, czy odbywają się wybory. $\mathrm{Na}$ pytanie o zamiarze głosowania 17,3\% respondentów odpowiedziało, że próbowali, ale nie mogli zagłosować, a $67 \%$ - że nie mają zamiaru iść do lokali wyborczych. Z grona tych, którzy nie mieli zamiaru głosować, 30,5\% wiedziało, że jest to niemożliwe (w tym $20,7 \%$ wiedziało, że ich dzielnica nie pracowała, 9,8\% - że w ich miejscowości wybory są w ogóle nieprzeprowadzane), 26,2\% powiedziało, że nie widzą odpowiedniego kandydata, $6,8 \%$ - że iść na wybory jest niebezpiecznie, 12,4\% nie wierzyło w przejrzystość wyborów, 7,7\% uważało, że ich region już nie jest częścią Ukrainy, inni nie mogą wziąć udziału przez względy rodzinne lub inne okoliczności ${ }^{28}$. Otóż dla obywateli Ukrainy udział w głosowaniu był i jest ważną sprawą, nawet nie zważając na to, że czasami sam fakt uczestnictwa jest bardziej ważny, niż poparcie jednego z kandydatów.

Tak więc zmiany w kulturze wyborczej Ukrainy w kierunku demokratyzacji stały się możliwe w latach 2004-2018 dzięki aktywnej oraz skutecznej działalności instytucji społeczeństwa obywatelskiego. Ich sukces był określany trzema czynnikami: ukształto-

26 Н. Ротар, Політична участь громадян Украйни у системних трансформаціях перехідного nеріоду: Монографія, Чернівці, Рута, 2007, с. 118-119.

27 Центральна виборча комісія України, http://www.cvk.gov.ua, Позачергові вибори Президента України 25.05.2014. Результати голосування по Україні, доступ: 24.02.2017

28 Фонд «Демократичні ініціативи імені Ілька Кучеріва», http://dif.org.ua, Вибори-2014: сподівання громадян, рейтинги кандидатів, мотивація вибору, доступ: 24.02.2017. 
wany fundament organizacyjny zrzeszeń społecznych, strukturę możliwości politycznych oraz symboliczny wpływ na obywateli i społeczności. Demokratyzacja kultury wyborczej przez organizacje społeczne na Ukrainie była zapewniona dzięki ustanowieniu rezonansu z normami kulturowymi, które były popierane przez większość obywateli Ukrainy.

W transformacji kultury wyborczej Ukrainy od praktyk autorytarnych do modelu demokratycznego istotną rolę pełniły również czynniki o charakterze cywilizacyjnym. Europejskie standardy cywilizacyjne Ukraińców w postaci tradycji historycznych, wartości kulturowych oraz mentalności mają znaczący wpływ na preferencje wyborcze wyborców. Właśnie one kształtują wybór pewnego typu narodowego lidera politycznego, który obecnie ostatecznie nabył cechy polityka europejskiego w oczekiwaniach większości obywateli Ukrainy. Jednocześnie pewne archetypy świadomości politycznej Ukraińców - etatyzm, kolektywizm, radykalizm polityczny ujawniają się w ich kulturze wyborczej w postaci orientacji etatystycznych, które w pewnym stopniu hamują ostateczną akceptację demokratycznego modelu kultury wyborczej na Ukrainie.

Streszczenie: Autorzy przeprowadzają analizę transformacji kultury wyborczej na Ukrainie od praktyk autorytarnych do modelu demokratycznego. Korzystanie z reguł metodologicznych współczesnej nauki politycznej, ukształtowanych w angielsko-amerykańskim dyskursie politologicznym, umożliwiły uzasadnienie tego, że zmiany w kulturze wyborczej Ukrainy w kierunku demokratyzacji stały się możliwe w latach 2014-2018. W tym procesie istotną rolę pełniły również czynniki o charakterze cywilizacyjnym. Europejskie stałe cywilizacyjne w postaci tradycji historycznych, wartości kulturowe oraz cechy mentalności mają istotny wpływ na preferencje elektoralne wyborców. Właśnie one kształtują wybór określonego rodzaju narodowego lidera politycznego, który współcześnie ostatecznie uzyskał cechy polityka europejskiego. Jednocześnie pewne archetypy świadomości politycznej Ukraińców - etatyzm, kolektywizm, radykalizm polityczny, uwidoczniają się w ich kulturze wyborczej w postaci orientacji na partię władzy, które z pewnym stopniu hamują ostatecznie zadomowienie się modelu demokratycznego kultury wyborczej na Ukrainie.

Słowa kluczowe: kultura wyborcza, proces wyborczy, udział w wyborach, Ukraina, wybory

\section{Transformation of Electoral Culture in Ukraine: From Authoritarian Practices to a Democratic Model}

Abstract: The body of the article goes on to discuss the problem of electoral culture transformation from authoritarian practices to a democratic model in Ukraine. The application of the methodological approaches of modern political science, formed in the Anglo-American political science discourse, made it possible for author to substantiate that it was the period between 2014 and 2018 that facilitated democratic positive tendency in the electoral culture of Ukraine. It should be articulated, that, of particular importance were civilization factors. European civilization constants, rooted in historical 
traditions, spiritual and cultural values and national mentality peculiarities, have a significant impact on voters' electoral preferences. Noteworthy, they impose on electors' decision to choose a certain national political leader, who has finally established himself as a European-style politician. Furthermore, such archetypes of Ukrainians' political consciousness as statism, collectivism, political radicalism are manifested in their electoral culture as a market-orientation when in power, which to some extent inhibit the final approval of the democratic model of electoral culture in Ukraine.

Keywords: electoral culture, electoral process, electoral participation, Ukraine, elections

\title{
Трансформация электоральной культуры в Украине: от авторитарных практик к демократической модели
}

\begin{abstract}
Аннотация: Авторы анализируют процесс трансформации электоральной культуры в Украине от авторитарных практик к демократической модели. Использование методологических принципов современной политической науки, сформированных в англо-американском политологическом дискурсе, позволили обосновать, что изменения в электоральной культуре Украины в направлении демократизации стали возможны в период 2014-2018 годов. В этом процессе существенную роль сыграли и факторы цивилизационного характера. Европейские цивилизационные константы в виде исторических традиций, культурных ценностей и особенностей менталитета существенно влияют на электоральные предпочтения избирателей. Именно они формируют выбор определенного типа национального политического лидера, который сегодня окончательно приобрел черты европейского политика. В то же время, определенные архетипы политического сознания украинцев - этатизм, коллективизм, политический радикализм, проявляются в их электоральной культуре в виде ориентаций на партию власти, которые в определенной степени тормозят окончательное утверждение демократической модели электоральной культуры в Украине.
\end{abstract}

Ключевые слова: электоральная культура, электоральный процесс, электоральное участие, Украина, выборы

\section{Bibliografia}

Electoral Cultures: American Democracy and Choice (Publikationen Der Bayerischen Amerika-akademie / Publications of the Bavarian American Academy), ed. by G. Banita, S. Pöhlmann. Universitätsverlag winter Heidelberg, 2015, vol. 16, p. 416.

Heath A., Perspectives of Electoral Behavior, "The Oxford Handbook of Political Behavior", ed. R. Dalton, H.-D. Kliengemann, Oxford, N.Y., Oxford University Press, 2007, p. 611-615.

Jackman R.W., Miller R.A., The Poverty of Political Culture, "American Journal of Political Science" 1996, vol. 40, № 3, August, p. 697-716. DOl: https://doi.org/10.2307/2111790.

Oxford Handbooks, http://www.oxfordhandbooks.com, L. M. Bartels, "The Study of Electoral Behavior", [in:] Oxford Handbook on American Elections and Political Behavior, ed. Jan Leighly.

Voting: A Study of Opinion Formation in a Presidential Campaign, ed. B.R. Berelson, F. Lazarsfeld, W.N. McPhee, Chicago, The University of Chicago Press, 1954, p. 395. 
Pobrane z czasopisma Wschód Europy http://journals.umcs.pl/we

Data: 26/04/2023 14:30:40

Transformacja kultury wyborczej na Ukrainie: od praktyk autorytarnych...

Байхельт Т., Павленко Р., Президентські вибори і конституційна реформа, [in:] Президентські вибори та Помаранчева революція: вплив на трансформаційні процеси в Україні, За ред. Г. Курта, К., Заповіт, 2005, с. 49-85.

Бекешкіна І.Е., Партії і партійне будівництво у соціологічному вимірі, [in:] Українське суспільство: десять років незалежності (Соціологічний моніторинг науковців), ред. В.М. Ворони, М.О. Шульги, К., Ін-т соціології НАНУ, 2001, с. 201-205.

Галата Я., Хто сильніше “засмаг”, “Демократична Україна” 2003, 29 серпня, с. 2.

Глебова И.И., Беспартийная власть и её партийная организация, [in:] Политическая наука в современной России: время поиска и контуры эволюции: Ежегодник 2004, М., РОССПЭН, 2004, с. 213-229.

Грінчак Т., Деякі аспекти проведення форумів демократичних сил під егідою блоку В.Ющенка "Наша Україна", "Україна: Події. Факти. Коментарі” 2003, № 20, с. 25-31.

Жданов І., Вибори-2002: соло для адміністративного ресурсу?, “Дзеркало Тижня” 2001, 22 грудня, c. 4.

Інформаційний портал депутатів, http://old.lvivrada.gov.ua, Програма партії Народний Союз «Наша Україна», доступ: 25.10.2018.

Литвин В.М., Україна: досвід та проблеми державотворення (90-ті роки XX ст.), К., Наукова думка, 2001, c. 560.

Ліга. Новости, http://news.liga.net, $B$ «Нашей Украине» оправдывают избрание Ющенко главой партии, доступ: 25.10.2018.

Мищак І., Організаційна розбудова партії НСНУ та заходи щодо підготовки до парламентських виборів, “Україна: Факти. Події. Коментарі” 2005, № 10, с. 39-48.

Опозиція в Україні (Аналітична доповідь Центру Разумкова, "Національна Безпека і Оборона” 2002, № 7, с. 2-41.

Паніна Н.В., Українське суспільство 1994-2005: соціологічний моніторинг, К., ТОВ „Видавництво Софія" 2005, с. 160.

Ротар Н., Політична участь громадян України у системних трансформаціях перехідного періоду: Монографія, Чернівці, Рута 2007, с. 472.

україна у нас одна!: Передвиборна програма Блоку «Наша Україна», "Голос України” 2006, № 35, 23 лютого, с. 4.

Україна, 2004 рік: перебіг президентської виборчої кампанії очима громадян, “Національна Безпека і Оборона" 2004, № 10, с. 2-20.

УHIAH, https://www.unian.ua, Ющенко переконаний, що у партії Наша Україна є майбутнє, доступ: 25.02.2017.

Фонд «Демократичні ініціативи імені Ілька Кучеріва», http://dif.org.ua, Вибори-2014: сподівання громадян, рейтинги кандидатів, мотивація вибору, доступ: 24.02.2017.

Центральна виборча комісія України, http://www.cvk.gov.ua, Передвиборча програма Блоку «Наша Україна - Народна самооборона» «Для людей - а не для політиків!», доступ: 25.10.2018.

Центральна виборча комісія України, http://www.cvk.gov.ua, Позачергові вибори Президента України 25.05.2014. Результати голосування по Україні, доступ: 24.02.2017

Якименко Ю., Литвиненко А., Жданов И., Кто и за что, с кем и против кого? Партии Украины за год до виборов, “Зеркало Недели” 2005, 2 апреля. 